JKKP: Jurnal Kesejahteraan Keluarga dan Pendidikan

http://doi.org/10.21009/JKKP

DOI: doi.org/10.21009/JKKP.051.04

E-ISSN: 2597-4521

\title{
PENGGUNAAN MEDIA GAMBAR UNTUK MENINGKATKAN MOTIVASI BELAJAR MATEMATIKA PADA SISWA KELAS 1 SDN 1 KEDIRI TAHUN PELAJARAN 2017/2018
}

\author{
Muhammad Fauzy ${ }^{1, a)}$, Khairun Nisa ${ }^{2, b)}$, Siti Istiningsih ${ }^{3, c)}$ \\ Email : ${ }^{c}$ ningistie@yahoo.co.id \\ ${ }^{1,2,3)}$ Program Studi S1 PGSD, Fakultas Keguruan Dan IImu Pendidikan \\ Universitas Mataram
}

\begin{abstract}
Abstrak
Motivasi belajar siswa dalam pembelajaran matematika mengenai penjumlahan dan pengurangan rendah. Untuk itu penelitian ini dilaksanakan. Tujuan skripsi ini adalah untuk meningkatkan motivasi belajar matematika mengenai penjumlahan dan pengurangan dengan media gambar pada siswa kelas I semester genap SD Negeri 1 Kedri Tahun 2017/2018. Untuk mencapai tujuan tersebut, peneliti mendasarkan pada teori-teori dan pengertian yang terkait dengan peningkatan motivasi belajar matematika mengenai penjumlahan dan pengurangan dengan media gambar. Penilitian tindakan kelas ini melalui empat tahap yaitu perencanaan, pelaksanaan, pengamatan dan refleksi yang dilaksanakan dalam dua siklus. Subjek dalam penelitian ini adalah 25 siswa kelas I SD Negeri Kediri. Teknik pengumpulan data melalui observasi, Angket Skala Motivasi dan dokumentasi. Teknis analisis data menggunakan analisis Deskriptif. Hasil analisis menunjukkan bahwa motivasi belajar siswa meningkat. Pada kondisi awal sebelum menggunakan media gambar ketercapaian motivasi belajar siswa $27.97 \%$. Setelah menggunakan media gambar pada siklus I ketercapaian motivasi belajar siswa meningkat yaitu $50.63 \%$. Karena belum tercapai yang di harapkan peneliti maka dilanjutkan siklus II. Dalam siklus II ketercapaian motivasi belajar siswa meningkat menjadi $80.85 \%$. Ketercapaian-ketercapaian motivasi belajar siswa dari siklus I ke siklus II meningkat $30.22 \%$. Berdasarkan hasil penelitian dapat disimpulkan bahwa dengan media gambar dapat meningkatkan motivasi belajar matematika mengenai penjumlahan dan pengurangan pada siswa kelas I SDN 1 kediri Tahun 2017/2018.
\end{abstract}

Kata kunci : Motivasi belajar, pembelajaran matematika, media gambar.

\section{Use of Media Images to Improve Mathematics Learning Motivation on the First Class Students in Basic School 1 Kediri 2017/2018 School Year}

\begin{abstract}
Students' motivation in mathematics learning about addition and subtraction low. For that the research was conducted. The purpose of this paper is to increase the motivation to learn math on addition and subtraction with media images on first grade second semester students of SD Negeri 1 Kedri Year 2017/2018. To achieve these goals, researchers based on theories and concepts associated with increased
\end{abstract}


motivation to learn math on addition and subtraction with media images. The studies of this class action through four stages: planning, implementation, observation and reflection conducted in two cycles. Subjects in this study were 25 students of class I Elementary School Kediri. The technique of collecting data through observation, inquiry and documentation Motivation Scale. Technical analysis of the data using descriptive analysis. The analysis showed that the students' motivation increases. In the initial conditions before using media images student motivation achievement of $27.97 \%$. After using media images in the first cycle increased student motivation achievement is $50.63 \%$. Because it has not achieved the expected researchers then followed the second cycle. In the second cycle students' achievement motivation increased to $80.85 \%$. The achievement of students' achievement motivation from the first cycle to the second cycle increased by $30.22 \%$. Based on the results of this study concluded that the media images can increase the motivation to learn mathematics of the addition and subtraction of first grade students at SDN 1 kediri Year 2017/2018.

Keywords: motivation to learn, mathematics, media images.

\section{PENDAHULUAN}

Hakikat dari proses pembelajaran adalah belajar, salah satunya belajar matematika. Matematika adalah suatu pelajaran yang tersusun secara beraturan, logis, berjenjang dari yang paling mudah hingga yang paling rumit (Hudoyo, 2001:44). Dengan demikian pelajaran matematika tersusun sedemikian rupa sehingga pengertian terdahulu lebih mendasari pengertian berikutnya. Dalam belajar matematika seorang guru perlu untuk menciptakan situasi dan suasana dimana siswa dapat aktif, kreatif, dan responsif pada lingkungan sekitar, salah satunya dengan menggunakan media pembelajaran untuk memotivasi siswa dalam belajar matematika tersebut.

Menurut Bruner (dalam Hudoyo, 2001:48) belajar matematika adalah belajar mengenai konsep konsep dan struktur-struktur matematika yang terdapat didalam materi yang dipelajari serta mencari hubungan antara konsep-konsep struktur-struktur matematika itu. Untuk dapat mengefektifkan pembelajaran, sekolah diharapkan menggunakan teknologi informatika dan komunikasi. seperti computer, alat peraga dan media lainnya. Bruner melalui teorinya mengungkapkan bahwa dalam proses belajar anak baiknya diberi memanipulasi benda-benda atau alat peraga yang dirancang secara khusus dan dapat diotak-atik oleh siswa dalam memahami konsep matematika

Berdasarkan hasil wawancara dengan wali kelas dan observasi pada siswa kelas I di SDN 1 Kediri, didapat informasi bahwa motivasi belajar siswa-siswi di sekolah ini cukup rendah. Hal itu dibuktikan dengan sikap siswa menunjukkan kurang semangat dalam mengikuti proses pembelajaran matematika. Fakta ini dilatar belakangi oleh proses belajar mengajar matematika yang dilakukan dengan hanya menggunakan media papan tulis tanpa ada media lain yang dapat meningkatkan motivasi belajar siswa, karena proses belajar mengajar yang dilakukan hanya dengan media itu tanpa ada variasi lain membuat siswa menjadi jenuh dan bosan dalam mendengarkan pelajaran matematika tersebut. Tidak hanya itu, nilai rata-rata matematika siswa juga masih dibawah rata-rata. Nilai pelajaran matematika siswa banyak diantaranya yang belum mencukupi KKM yang telah ditentukan sekolah yakni 75 .

Menurut Suherman (2003:197) bahwa siswa mempunyai masalah dalam motivasi belajar matematikanya diantaranya cenderung untuk menghindari pelajaran matematika, siswa gagal dalam melakukan tugas-tugas matematika dan siswa menolak untuk mengikuti kegiatan-kegiatan matematika, baik di dalam maupun di luar kelas. Hal ini sejalan dengan hasil observasi sehingga dapat diindikasikan bahwa siswa kelas 1 SDN 1 Kediri memiliki motivasi belajar yang rendah. 
Siswa belajar karena didorong oleh kekuatan mentalnya, kekuatan mental itu berupa keinginan, perhatian, kemauan atau cita-cita. Kekuatan mental tersebut dapat tergolong rendah atau tinggi. Ada ahli psikologi pendidikan yang menyebut kekuatan mental yang mendorong terjadinya belajar tersebut sebagai motivasi belajar. Motivasi dipandang sebagai dorongan mental yang menggerakkan dan mengarahkan prilaku manusia, termasuk prilaku belajar.

Motivasi merupakan faktor yang sangat penting dalam belajar, tanpa adanya motivasi seorang siswa menjadi malas dalam melakukan aktivitas belajar, seorang siswa yang mempunyai intelegensi tinggi pun belum tentu berhasil bila tidak ada yang memotivasi dalam proses belajar mengajar.

Guru perlu kreatif dalam menyampaikan pelajaran dengan menggunakan media, metode dan strategi pembelajaran yang bervariasi, sehingga siswa sebagai penerima materi pelajaran menjadi termotivasi dan semangat dalam mengikuti pelajaran. Cara ini perlu dilakukan mengingat siswa di kelas rendah cenderung memerlukan benda-benda nyata (konkret) untuk memudahkan memahami pelajaran. Kenyataan ini menjadi tantangan tersendiri bagi guru-guru yang mengajar di kelas rendah untuk membuat siswa menjadi mengerti dengan materi yang guru jelaskan.Salah satu cara yang dapat memotivasi siswa sekolah dasar dalam proses belajar mengajar yaitu dengan menggunakan media dalam proses pembelajaran. Media gambar merupakan salah satu dari media pembelajaran yang paling umum dipakai dan merupakan bahasa yang umum dan dapat dimengerti dan dinikmati dimana-mana.

Menurut Sadiman (2013:21), media gambar adalah suatu gambar yang berkaitan dengan materi pelajaran yang berfungsi untuk menyampaikan pesan dari guru kepada siswa. Media gambar ini dapat membantu siswa untuk mengungkapkan informasi yang terkandung dalam masalah sehingga hubungan antar komponen dalam masalah tersebut dapat terlihat dengan lebih jelas.

Menurut Purwanto dan Alim (dalam Permanarian 2010 : 23), kelebihan media gambar adalah: 1) Sifatnya konkrit, gambar lebih realistis menunjukkan pokok masalah dibandingkan dengan media verbal semata, 2) Gambar dapat mengatasi batasan ruang dan waktu, 3) Media gambar dapat mengatasi keterbatasan pengamatan, 4) Dapat memperjelas suatu masalah, dalam bidang apa saja, 5) Murah harganya, mudah didapatkan dan digunakan. Dengan menggunakan media gambar dalam belajar matematika ini motivasi siswa dapat meningkat, karena ditunjang dengan bentuk medianya yang menarik, dan juga mempunyai bermacam-macam warna, sehingga menimbulkan proses belajar yang aktif, kreatif dan menyenangkan karena menggunakan media yang sesuai dengan karakteristik siswa.

Dengan menggunakan media pembelajaran akan memudahkan siswa dalam menerima dan mengingat materi yang telah disampaikan. Bahwa pemakaian media dalam proses belajar mengajar keingintahuan dan minat baru bagi siswa, serta membangkitkan motivasi dan rangsangan kegiatan belajar mengajar dan bahkan membawa pengaruh psikologis terhadap siswa. (Azhar, 2013:15)

Berdasarkan uraian di atas, peneliti termotivasi untuk melakukan penelitian tindakan kelas dengan mengangkat judul "Penggunaan Media Gambar Untuk Meningkatkan Motivasi Belajar Matematika Pada siswa Kelas I SDN 1 Kediri Tahun Pelajaran 2017/2018 ". Peneliti mengambil materi penjumlahan dan pengurangan karena ini merupakan materi awal dalam pembelajarn yang di ajarkan pada siswa kelas 1 SD selain itu kebanyakan siswa belum memahami tentang materi tersebut.

\section{TINJAUAN PUSTAKA}

\section{Motivasi Belajar Matematika}

Motivasi dan belajar merupakan dua hal yang saling mempengaruhi.Setiap anak yang lahir memiliki motivasi belajar. Motivasi berasal dari kata motif yang berarti kekuatan yang terdapat dalam diri individu, yang menyebabkan individu itu bertindak dan berbuat (Hamzah, 2014: 3). Dalam hal 
ini,beliau menegaskan bahwa motif tidak dapat diamati secara langsung, tetapi dapat diinterprestasikan dari tingkah lakunya, berupa dorongan, rangsangan, atau pembangkit tenaga untuk melakukan sesuatu. Santrock (2014: 120$)$ berpendapat bahwa motivasi melibatkan proses yang memberikan energi, mengarahkan, dan mempertahankan perilaku.

Sardiman (2016: 73) menjelaskan bahwa motif diartikan sebagai daya upaya yang mendorong seseorang untuk melakukan sesuatu dan digunakan sebagai daya penggerak di dalam subjek untuk melakukan aktifitas-aktifitas tertentu demi mencapai suatu tujuan. Dalam kegiatan belajar mengajar, motivasi dikatakan sebagai keseluruhan daya penggerak di dalam diri siswa yang menimbulkan kegiatan belajar, yang akan menjamin kelangsungan kegiatan belajar siswa dan memberikan arah pada kegiatan belajarnya, sehingga tujuan yang diinginkan siswa dapat tercapai. Selain itu, motivasi diartikan sebagai suatu kondisi yang menyebabkan atau menimbulkan perilaku tertentu dan yang memberi arah dan ketahanan pada tingkah laku tersebut.

\section{Media Gambar}

Menurut Sadiman (2013: 29), mengatakan bahwa Media gambar adalah media yang paling umum dipakai gambar merupakan bahasa yang umum, yang dapat dimengerti dan dinikmati dimana-mana. Oleh karena itu, pepatah cina yang gatakan bahwa sebuah gambar berbicara lebih banyak dari pada seribu kata.

Arsyad (2013: 2), mengatakan bahwa disamping mampu menggunakan alat-alat yang tersedia, guru juga dituntut untuk dapat mengembangkan ketrampilan membuat media pembelajaran yang akan digunakannya apabila media tersebut belum tersedia. Untuk itu guru harus memiliki pengetahuan dan pemahaman yang cukup tentang pengembangan media pembelajaran

Pada umumnya anak Sekolah Dasar masuk pendidikan Sekolah Dasar padausia 6-7 tahun dengan rentang waktu belajar di SD selama 6 tahun maka usia anak Sekolah Dasar bervariasi antara 6-12 tahun. Menurut Izzaty (2008:104) usia ini artinya bahwa mereka masih termasuk dalam kategori operasional konkret. Sehingga dalam proses pembelajarannya masih membutuhkan suatu perantara yang bisa menggambarkan hal-hal yang abstrak kedalam bentuk yang konkret agar dapat ditangkap oleh siswa. Memasukan hal abstrak ke dalam bentuk konkret yang sederhana adalah dengan menggunakan gambar. Jadi menggunakan media gambar untuk pembelajaran terutama di sekolah dasar merupakan hal yang tepat.

\section{METODOLOGI PENELITAN}

\section{Rancangan Penelitian}

Desain penelitian tindakan kelas ini menggunakan model spiral Kemmis dan Taggart yang terdiri dari siklus-siklus. Penelitian ini dilaksanakan dalam beberapa siklus dengansetiap siklusnya terdiri dari tahapan-tahapan, yaitu: perencanaan (planning), tindakan(action) dan pengamatan (observation), dan refleksi (reflection) (Arikunto,2014: 93).

\section{Populasi dan Sampel Penelitan}

Sampel adalah bagian dari jumlah dan karakteristik yang dimiliki oleh populasi tersebut. Dalam menentukan sampel yang akan digunakan dalam penelitian maka digunakan teknik sampling jenuh. Sampling jenuh adalah teknik penentuan sampel bila semua anggota populasi digunakan sebagai sampel. Berdasarkan teknik sampling yang digunakan maka sampel penelitian adalah siswa kelas I SDN 1 Kediri yang berjumlah 25 siswa terdiri dari 15 siswa perempuan dan 10 siswa lakilaki. Data yang diperoleh ketika observasi di kelas 1 yaitu sebagian besar siswa memiliki motivasi belajar yang rendah pada pelajaran Matematika. 


\section{Metode Pengumpulan Data}

Metode pengumpulan data yang diunakan dalam penelitan ini antaralain :

1. Observasi dilakukan untuk melakukan untuk mengamati aktivitas belajar siswa dan aktivitas mengajar guru selama pembelajaran membaca teks pendek menggnakan media gambar berlangsung.

2. Angket Skala Motivasi Belajar, Angket merupakan teknik pengumpulan data yang dilakukan dengan cara memberi seperangkat pertanyaan atau pernyataan tertulis kepada responden untuk dijawabnya. Dalam penelitian yang akan dilakukan angket atau kuesioner akan digunakan untuk memperoleh data tentang motivasi belajar matematika, dalam hal ini siswa di damping dalam mengisi angket skala motivasi belajar.

3. Dokumentasi, Dokumentasi adalah suatu yang tercetak, terekam dan tertulis yang dapat dipakai sebagai bukti bahwa suatu penelitian benar-benar sudah dilakukan sesuai dengan perencanaan sebelumnya sepeti RPP, Instrumen Penelitian, hasil kerja siswa dan juga dalam bentuk foto pada saat proses pembelajaran berlangsug

\section{Instrumen Penelitian}

Instrumen penelitian adalah alat bantu yang dipilih dan digunakan oleh peneliti dalam kegiatannya mengumpulkan data agar kegiatan tersebut menjadi sistematis dan dipermudah olehnya. Adapun instrumen yang digunakan peneliti adalah lembar observasi yang terdiri lembar observasi siswa dan guru, skala motivasi belajar dan dokumentasi.

\section{Metode Analisis Data}

A. Analisis Aktivitas Guru

Banyak indikator : 35

Jenis skala : Skala Guttman

Skor Maksimal : 35

Skor Minimal : 0

Skor $\quad: \frac{\text { Jumlah skor yang diperoleh }}{\text { Jumlah skor maksimal }} \times 100 \%$

Tabel 1. Kriteria aktivitas Guru

\begin{tabular}{cc}
\hline Persentase Skor $(X)$ & Kategori \\
\hline $\mathbf{7 5 \%}<X \leq \mathbf{1 0 0} \%$ & Tinggi \\
$\mathbf{5 0 \%}<X \leq \mathbf{7 5 \%}$ & Cukup \\
$\mathbf{2 5 \%}<X \leq \mathbf{5 0 \%}$ & Rendah \\
$\mathbf{0 \%}<\mathrm{X} \leq \mathbf{2 5 \%}$ & Sangat Rendah \\
\hline
\end{tabular}

B. Analisis Aktivitas Siswa

Banyak indikator : 5 (10 sub indikator)

Jenis skala : Skala Likert

Skor

Mean ideal (Mi)

$=1 / 2($ skor tertinggi + skor terendah $)$

Standar Deviasi ideal (SDi)

Skor Maksimal

$=1 / 6$ (skor tertinggi-skor terendah)

Skor minimal

$: 40$

$: 10$ 
Tabel 2. Kriteria Aktivitas Siswa secara Individu

\begin{tabular}{ccc}
\hline \multicolumn{2}{c}{ Skor $(\mathbf{X})$} & Kriteria \\
\hline $\mathbf{M i + 1 , 5 S D i}<\mathbf{X} \leq$ & $32.5<\mathrm{X} \leq$ & Sangat Tinggi \\
$\mathbf{M i}+\mathbf{3 S D i}$ & 40 & \\
$\mathbf{M i + 0 , 5 S D i}<\mathbf{X} \leq$ & $27.5<\mathrm{X} \leq$ & Tinggi \\
$\mathbf{M i + 1 , 5 S D i}$ & 32.5 & \\
$\mathbf{M i - 0 , 5 S D i}<\mathbf{X} \leq$ & $22.5<\mathrm{X} \leq$ & Sedang \\
$\mathbf{M i + 0 , 5 S D i}$ & 27.5 & \\
$\mathbf{M i}-\mathbf{1 , 5 S D i}<\mathbf{X} \leq \mathbf{M i}-$ & $17.5<\mathrm{X} \leq$ & Rendah \\
$\mathbf{0 , 5 S D i}$ & 22.5 & \\
$\mathbf{M i}-\mathbf{S S D i}<\mathbf{X} \leq \mathbf{M i}-$ & $10<\mathrm{X} \leq$ & Sangat Rendah \\
$\mathbf{1 , 5 S D i}$ & 17.5 & \\
\hline
\end{tabular}

Tabel 3. Kriteria Persentase Aktivitas Siswa Secara Klasikal

\begin{tabular}{cc}
\hline Persentase Skor $(X)$ & Kategori \\
\hline $\mathbf{7 5 \%}<X \leq \mathbf{X 0 0} \%$ & Tinggi \\
$50 \%<X \leq 75 \%$ & Cukup \\
$25 \%<X \leq 50 \%$ & Rendah \\
$0 \%<X \leq \mathbf{2 5 \%}$ & Sangat Rendah \\
\hline
\end{tabular}

C. Analisis Motivasi Belajar Matematika Siswa

$\begin{array}{lll}\text { Banyak indikator } & : 6 \text { (30 deskriptor) } & \\ \text { Jenis skala } & : \text { Skala Guttman } & \\ \text { Skor } & : & \\ \quad \text { Mean ideal (Mi) } & =1 / 2 \text { (skor tertinggi+skor terendah) } \\ \text { Standar Deviasi ideal (SDi) } & =1 / 6 \text { (skor tertinggi-skor terendah) } \\ \text { Skor Maksimal } & : 30 \\ \text { Skor minimal } & : 0\end{array}$

Tabel 4. Kriteria motivasi belajar matematika siswa

\begin{tabular}{|c|c|c|}
\hline \multicolumn{2}{|c|}{ Skor (X) } & Kriteria \\
\hline $\begin{array}{c}\mathrm{Mi}+1,5 \mathrm{SDi}<\mathrm{X} \leq \\
\mathrm{Mi}+3 \mathrm{SDi}\end{array}$ & $\begin{array}{c}22.5<X \leq \\
30\end{array}$ & Sangat Tinggi \\
\hline $\begin{array}{c}\mathrm{Mi}+0,5 \mathrm{SDi}<\mathrm{X} \leq \\
\mathrm{Mi}+1,5 \mathrm{SDi}\end{array}$ & $\begin{array}{c}17.5<X \leq \\
22.5\end{array}$ & Tinggi \\
\hline $\begin{array}{c}\mathrm{Mi}-0,5 \mathrm{SDi}<\mathrm{X} \leq \\
\mathrm{Mi}+0,5 \mathrm{SDi}\end{array}$ & $\begin{array}{c}12.5<\mathrm{X} \leq \\
17.5\end{array}$ & Sedang \\
\hline $\begin{array}{c}M i-1,5 S D i<X \leq M i- \\
0,5 S D i\end{array}$ & $\begin{array}{c}7.5<X \leq \\
12.5\end{array}$ & Rendah \\
\hline 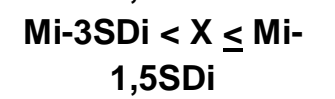 & $0<X \leq 7.5$ & Sangat Rendah \\
\hline
\end{tabular}


Tabel 5. Kriteria Persentase Motivasi Belajar Matematika Siswa

\begin{tabular}{cc}
\hline Persentase Skor $(X)$ & Kategori \\
\hline $\mathbf{7 5 \%}<\mathbf{X} \leq \mathbf{1 0 0 \%}$ & Tinggi \\
$\mathbf{5 0} \%<\mathrm{X} \leq \mathbf{7 5 \%}$ & Cukup \\
$\mathbf{2 5 \%}<\mathrm{X} \leq \mathbf{5 0 \%}$ & Rendah \\
$\mathbf{0 \%}<\mathrm{X} \leq \mathbf{2 5 \%}$ & Sangat Rendah \\
\hline
\end{tabular}

\section{HASIL PENELITAN DAN PEMBAHASAN}

Penelitian Tindakan kelas ini dalam pelaksanakannya digunakan pencarian data awal sebelum pemberian tindakan pada saat Pratindakan lalu dilanjutkan dengan pemberian tindakan dalam 2 siklus dan masing masing siklus menggunakan 2 kali pertemuan.

\section{A. Data Aktivitas Guru}

Kegiatan guru dalam pembelajaran matematika menggunakan media gambar diamati oleh peneliti dengan menggunakan lembar observasi yang terdiri dari 35 butir. Adapun hasil observasi aktivitas guru secara rinci dijabarkan sebagai berikut.

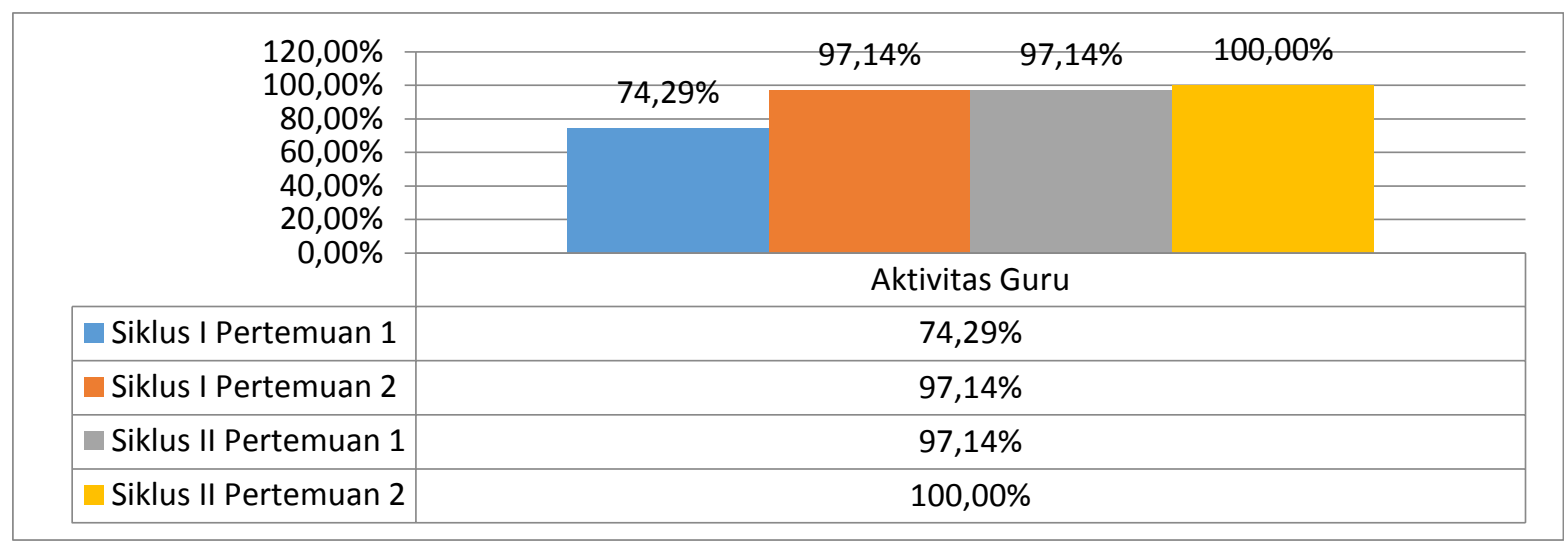

Grafik 1. Histogram Aktivitas Guru pada Siklus I pertemuan 1, Siklus I pertemuan 2, Siklus II pertemuan 1 dan Siklus II pertemuan 2

Pada siklus I pertemuan pertama aktivitas guru sebesar $74,29 \%$ dan pertemuan kedua 97,14\%. Berdasarkan hasil observasi siklus I menggambarkan kegiatan guru dalam pembelajaran matematika menggunakan media gambar belum maksimal sehingga mempengaruhi aktivitas siswa dan hasil skala motivasi siswa. Penerapan media gambar dalam pembelajaran matematika siklus I yang dilakukan guru, ditemukan kendala-kendala yaitu media gambar kurang bervariasi sehingga siswa belem menunjukan ketertarikan yang signifikan dan siswa juga malu menjawab pertanyaan dari guru, masih ada siswa yang keluar kelas tanpa ijin kepada guru, sebagian siswa mengerjakan tugas lain selain yang diperintahkan guru, sebagian siswa bermain dan ngobrol sendiri, dan siswa yang mendapat reward siswa yang itu-itu saja/ belum merata. Kemudian pada siklus II kendala-kendala tersebut diperbaiki. Perbaikan dalam kegiatan pembelajaran yang dilakukan guru antara lain menambah variasi media gambar,lebih memotivasi siswa untuk bertanya dan menjawab pertanyaan guru dengan memberikan reward verbal maupun non verbal, memberikan pengawasan lebih agar siswa tidak keluar kelas dengan alasan yang jelas dan atas ijin guru, memberikan perhatian secara merata kepada 
semua siswa agar tidak ada siswa yang mengerjakan tugas lain, mendesain pembelajaran lebih menarik agar siswa fokus pada pembelajaran, dan memberikan kesempatan kepada semua siswa agar mendapatkan reward secara merata.

Siklus II pertemuan pertama mencapai $97,14 \%$ dan pertemuan kedua mencapai $100 \%$. Berarti dapat disimpulkan bahwa terdapat peningkatan aktivitas guru dari siklus 1 ke siklus 2, baik pada pertemuan pertama maupun kedua. Peningkatan aktivitas guru juga memberikan dampak pada meningkatnya aktivitas siswa dan hasil skala motivasi belajar siswa.

\section{B. Data Aktivitas Siswa}

Hasil observasi aktivitas siswa kelas 1 SDN 1 Kediri menunjukkan adanya peningkatan setelah diterapkannya media gambar pada pembelajaran matematika dari pratindakan ke siklus I pertemuan 1 dan 2, dan dari siklus I ke siklus II pertemuan 1 dan 2. Secara rinci peningkatan aktivitas siswa secara klasikal disajikan dalam gambar di bawah ini.

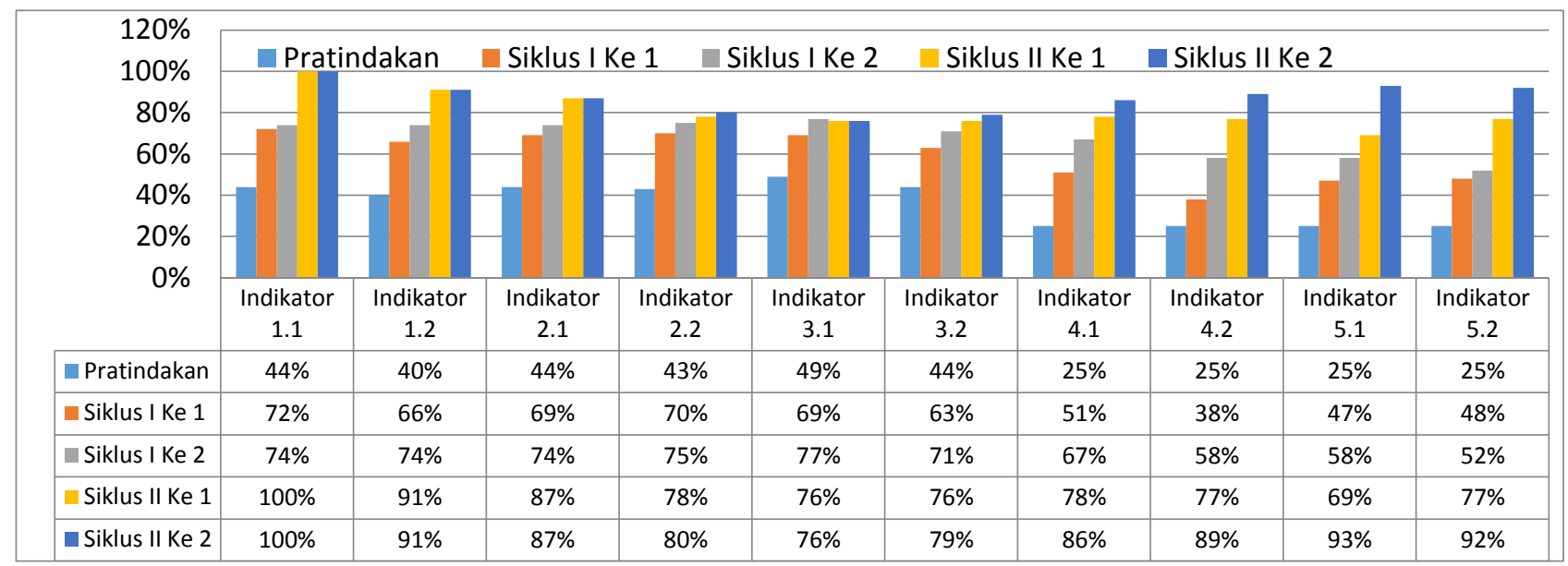

Grafik 3. Histogram Aktivitas Siswa secara klasikal pada Pratindakan, Siklus I pertemuan 1, Siklus I pertemuan 2, Siklus II pertemuan 1 dan Siklus II pertemuan 2

Secara individu, aktivitas siswa juga mengalami peningkatan setelah diterapkannya penggunaan media gambar pada pembelajaran matematika dari pratindakan ke siklus I pertemuan 1 dan 2, dan dari siklus I ke siklus II pertemuan 1 dan 2 . Secara rinci peningkatan aktivitas siswa secara individu disajikan dalam gambar di bawah ini. 


\begin{tabular}{|c|c|c|c|c|c|}
\hline - PRATIABAKAN & Siklus I ke 1 & \multicolumn{2}{|c|}{ Siklus I ke 2} & \multicolumn{2}{|c|}{ Siklus II ke 2} \\
\hline \multicolumn{6}{|l|}{$100 \%$} \\
\hline \multicolumn{6}{|l|}{$80 \%$} \\
\hline \multicolumn{6}{|l|}{$60 \%$} \\
\hline $40 \%$ & & & & & \\
\hline \multicolumn{6}{|l|}{$20 \%$} \\
\hline \multirow{2}{*}{$0 \%$} & $n$ & & & & \\
\hline & $\begin{array}{l}\text { Sangat } \\
\text { Rendah }\end{array}$ & Rendah & Sedang & Tinggi & Sangat Tinggi \\
\hline PRATINDAKAN & $4 \%$ & $96 \%$ & $0 \%$ & $0 \%$ & $0 \%$ \\
\hline Siklus I ke 1 & $0 \%$ & $8 \%$ & $32 \%$ & $60 \%$ & $0 \%$ \\
\hline Siklus I ke 2 & $4 \%$ & $32 \%$ & $48 \%$ & $16 \%$ & $0 \%$ \\
\hline Siklus II ke 1 & $0 \%$ & $0 \%$ & $0 \%$ & $68 \%$ & $32 \%$ \\
\hline Siklus II ke 2 & $0 \%$ & $0 \%$ & $0 \%$ & $8 \%$ & $92 \%$ \\
\hline
\end{tabular}

Grafik 3. Histogram Aktivitas Siswa secara individu pada Pratindakan, Siklus I pertemuan 1, Siklus I pertemuan 2, Siklus II pertemuan 1 dan Siklus II pertemuan 2

\section{Data Motivasi Belajar Matematika Siswa}

Berdasarkan hasil skala motivasi belajar siswa kelas 1 SD N 1 Kediri menunjukkan adanya peningkatan motivasi belajar siswa setelah diterapkannya media gambar pada pembelajaran matematika. Peningkatan skala motivasi belajar siswa dianalisis secara klasikal dan secara individu. Peningkatan skala motivasi belajar siswa ditunjukkan dengan ketercapaian keenam indikator yaitu Hasrat dan keinginan berhasil, Dorongan dan kebutuhan dalam belajar, Adanya harapan dan cita-cita masa depan, Penghargaan dalam belajar, Kegiatan yang menarik dalam belajar, dan Lingkungan belajar yang kondusif. Peningkatan skala motivasi belajar siswa secara klasikal disajikan dalam gambar di bawah ini

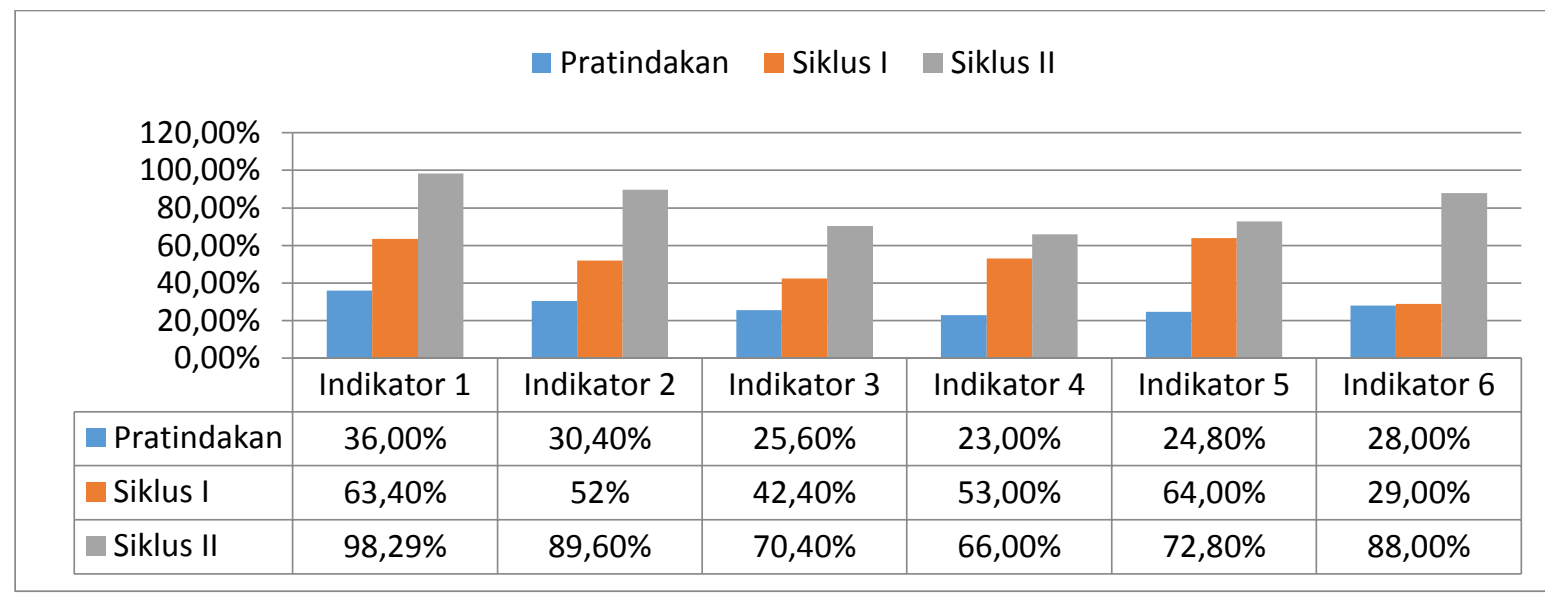

Grafik 4. Histogram Skala Motivasi Siswa secara klasikal pada Pratindakan, Siklus I dan Siklus II

Sedangkan ditinjau secara individu, pencapaian hasil skala motivasi dari pratindakan ke siklus I, dari siklus I ke siklus II mengalami peningkatan Peningkatan tersebut dapat disajikan dalam gambar di bawah ini 


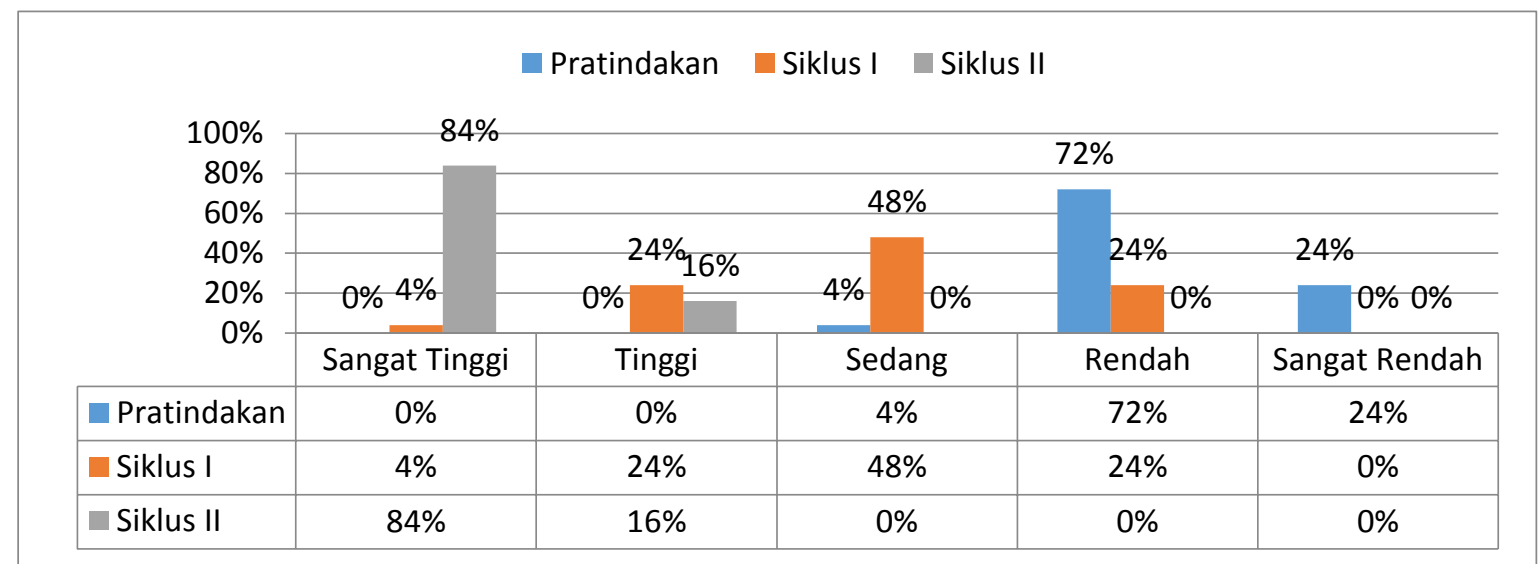

Grafik 5. Histogram Skala Motivasi Siswa secara individu pada Pratindakan, Siklus I dan Siklus II

\section{KESIMPULAN}

Penelitian ini adalah penelitian menggunakan model spiral Kemmis dan Taggart. Berdasarkan hasil analisis dan pengujian maka dapat ditarik kesimpulan sebagai berikut :

1. Penilitian tindakan kelas ini melalui empat tahap yaitu perencanaan, pelaksanaan, pengamatan dan refleksi yang dilaksanakan dalam dua siklus. Subjek dalam penelitian ini adalah 25 siswa kelas I SD Negeri Kediri.

2. Teknik pengumpulan data melalui observasi, Angket Skala Motivasi dan dokumentasi. Teknis analisis data menggunakan analisis Deskriptif. Hasil analisis menunjukkan bahwa motivasi belajar siswa meningkat.

3. Pada kondisi awal sebelum menggunakan media gambar ketercapaian motivasi belajar siswa $27.97 \%$. Setelah menggunakan media gambar pada siklus I ketercapaian motivasi belajar siswa meningkat yaitu $50.63 \%$.

4. Karena belum tercapai yang di harapkan peneliti maka dilanjutkan siklus II. Dalam siklus II ketercapaian motivasi belajar siswa meningkat menjadi $80.85 \%$. Ketercapaianketercapaian motivasi belajar siswa dari siklus I ke siklus II meningkat $30.22 \%$.

5. Berdasarkan hasil penelitian dapat disimpulkan bahwa dengan media gambar dapat meningkatkan motivasi belajar matematika mengenai penjumlahan dan pengurangan pada siswa kelas I SDN 1 kediri Tahun 2017/2018.

\section{DAFTAR PUSTAKA}

Arief, Sadiman, dkk. 2013. Media pendidikan: pengertian, pengembangan, dan pemanfaatannya. PT Raja Grafindo Persada. Jakarta

Arikunto, Suharsimi. 2014. Dasar-dasar Evaluasi Pendidikan. Aneka Cipta: Jakarta

Arsyad, Azhar 2013. Media Pembelajaran. PT Raja Grafindo Persada : Jakarta

Dimyanti .2013. Belajar dan Pembelajaran. Rineka Cipta : Jakarta

Eman, Suherman, dkk. 2003 Strategi Pembelajaran Matematika Kontemporer. UPI Press : Jakarta Hamzah B. Uno. 2014, Teori Motivasi dan Pengukurannya, Analisis di Bidang Pendidikan. Bumi

Aksara : Jakarta

Hudoyo, Herman. 2001. Strategi belajar mengajar matematika. IKIP Malang : Malang

Izzaty, Rita Eka .2008. Perkembangan Peserta Didik.UNYPress : Yogyakarta 
Permanarian S. dan Anastasia F. R. 2010 Peningkatan Kemampuan Membaca Permulaan pada Anak Tunarungu melalui Metode SAS dengan Animasi. E-Jurnal UPI: JASSI Anakku Vol. 9 No. 2 akses 13 januari 2017

Santrock, J.W. 2014. Psikologi Pendidikan (edisi kedua). (Penerj. Tri Wibowo B.S).Kencana : Jakarta

Sardiman A.M. 2016. Interaksi dan Motivasi Belajar Mengajar. PT. Rajawali Pers: Jakarta

Sutarto dan Syarifuddin. 2013. Desain pembelajaran Matematika.Penerbit Samudra Biru : Yogyakarta 